\title{
FATIMA AND THE VALUES OF CONTEMPORARY SOCIETY: AN ESSAY
}

\author{
Paulo Nuno MARTINS, \\ Researcher, PhD History and Philosophy of Science (FCT-UNL),Centre Internationale de \\ Recherche et d'Études Transdisciplinaire, CIRET, Paris; Transdisciplinary Center for \\ Consciousness Studies, CTEC, University Fernando Pessoa of Oporto, Portugal; \\ Interuniversity Center for History of Science and Technology, CIUHCT, New University of \\ Lisbon, PORTUGAL; \\ E-mail: paulonunom@gmail.com
}

\begin{abstract}
The aim of this article is to address the theme of the role of Fatima in the context of the values in contemporary society, trying to make the comparison of the content of the «Message of Fatima» with some contemporary «Marian Messages» received by the "seers" Marija Pavlovic and Patrícia Talbot.
\end{abstract}

Keywords: role of Fátima in the changing values; most relevant aspects of Fatima; religious geography.

\section{INTRODUCTION}

This article aims to address the "Message of Fatima" as a source of changing values in contemporary societies. Recently, our contemporary has gone through a financial "crisis" and another is foreseen in the near future (according to some analysts), which from my point of view is the result of a deeper "crisis": ethics or personal values. Throughout history [1], particularly in 20th century, such an event occurred in some fundamental milestones where politicians have sought to solve the problems of society by extolling a "radical nationalism" defended by nazism, which led to World War II, as well as an "utopian idealism" advocated by communism in the Soviet Union, which promoted the prohibition of the sacred after the end of World War II, giving rise to the separation of Eastern and Western cultures by the construction of a wall in Berlin (Europe) that has already fallen.

For its part, in the history of mankind there have been several Marian Apparitions[2], namely in wartime, such as in the first half of the 20th century, in 1917, in Portugal (Fatima), at the time of World War I and whose "Message" has spoken of a probable World War II, during the second half of the 20th century. In the same way, in the 1980s, in BosniaHerzegovina (Medjugorje), at the time of the war in the Balkans, and in Ecuador (El Cajas), there were also some Marian Apparitions (both of them awaiting validation by the Vatican) that have called for a changing values in contemporary society. It is true that throughout history several "crises" have occurred on Earth and mankind has always found the way to get out of them. However, nowadays humanity has the possibility of destroy itself without possibility of reversing the process. This "potential" destruction has several dimensions: physical/biological, psychological and spiritual. Most positively, every human being is free to choose to evolve in terms of self-awareness that might lead to a better future and destiny for humanity [3]. In this regard, this article on Fatima seeks to address the theme of values through some examples given by the little shepherds of Fatima who have shown love, light and grace, during their life on Earth [4]. 


\section{FATIMA AND THE VALUES OF CONTEMPORARY SOCIETY: AN ESSAY}

The role of the "Message of Fatima" to the values of contemporary society is something that has brought together different cultures over time.

In this regard, Daniel Reju [5] argues that «the fact that the Fatima Apparitions have taken place in 1917 is by no means a matter of chance... To the dead and wounded of the World War I of 1914-1917, we have to add several unbelievers because of this genocide. The fact that the Virgin referred to Russia, reinforces the connection of the "Message of Fatima" and the destiny of this nation through the rediscovery of the Icon of Kazan in the 16th century by a child (called "Matrona") who placed the image in a convent in Moscow, until its disappearance during the Bolshevik Revolution of 13th October in 1917 (coinciding with the last Fatima Apparition). This Icon remained in Fatima between 1973-1993, and at the Vatican between 1994-2004, and returned to Russia through Pope John Paul II, after the change of political regime» ${ }^{1}$.

In historical terms, José Franco [6] states that the religious, public and spontaneous gathering in Fatima that occurred in 1917, had great impact on Portuguese society at that time, namely, between the peaceful and conservative attitude of the Catholic Church and the radical Republican perspective of the Portuguese state that defended the Portuguese military presence in War World I. However, in 1926, the change of political regime in Portugal facilitated the recognition of the "Message of Fatima", and since 1930 it has gained increasing prominence in national Catholicism. At the same time, a growing spread of the "Fatima Message" throughout the world was made by Pope Pius XII.

Meanwhile, Sister Lucy was unable to become a nun in a convent in Portugal, and so she went to Pontevedra and Tuy until 1948, during the Spanish Civil War (1936-1939) that took place between the Republicans (who were supported by the communism of the Soviet Union) and Franco (defender of fascism). In this regard, Sister Lucy referred to the need for the «consecration of Russia in order to minimize the "errors of communism" throughout the world»". For its part, Nazism also saw the peaceful "Message of Fatima" as a threat to its destructive goals. It is within this context that we could see that the "Message of Fatima" did not appeal to both sides of the war conflict. So, Sister Lucy stated that «Salazar was chosen to govern Portugal through a peacekeeping attitude; during wartime ... although the large amount of Portuguese gold reserves should be distributed by the Portuguese population in order to meet their basic needs» ${ }^{3}$. For his part, Salazar saw in Fatima a political and spiritual usefulness, namely in promoting the Portuguese nationalism of his regime, as stated by the Portuguese daily newspaper "Novidades": "Fatima is the place where all regions and social classes of Portugal might be united in a "unique vibration" 4 ".

Historically, after the end of World War II, the "Cold War" between the Soviet Union (communism) and the United States of America (capitalism) occurred in the world. In this regard, Pope Pius XII asked to the Portuguese people «to pray in Fatima to the "Queen of Peace" in order to help all humanity to find peace and rise from the ruins»". It is within this context that the "Blue Army of Our Lady of Fatima" has arisen near the Basilica of Fatima with the purpose of keeping the symbolic Icon of Kazan safe, before returning to Russia. Meanwhile, during the John Paul II pontificate the "Message of Fatima" became a "Global Phenomena" because many events referred to in this Divine Message began to occur in the world. In fact, it was during the John Paul II pontificate that Mikhail Gorbachev began the process of "perestroika" ("change", "revolution"), leading to the end of the "Cold War".

$\overline{1,2,3,4,5,6,8,9,10,11,12,13}$ English translation is my responsibility 
Furthermore, some other events described in the "Message of Fatima" began to "come to fruition", namely the failed attempt on Pope John Paul II, on 13th May 1981 (commemoration of Fatima Apparitions), in 1989, the "coincident" fall of the "Berlin Wall" together with the fall of communist regimes throughout Europe, in accordance with the Virgin's expression: «At last, My Immaculate Heart will triumph» ${ }^{6}$. Meanwhile, the Pope John Paul II decided to consecrate the whole world (including the Russia) to the Divine Mother, as requested by Sister Lucy. All these events were announced by the mass media (newspapers, radio, and television) that contributed to Fatima becoming a Sacred global place, in the context of the contemporary Catholicism.

Nowadays, there are some examples of similarities between the "Message of Fatima" and some Marian Apparitions that have occurred both with Marija Pavlovic [7] (along with other "seers"), in the 1980s, in Medjugorje (Bosnia-Herzegovina), and Patricia Talbot [8], in the 1990s, in El Cajas (Ecuador), and so reinforcing the role of the "Message of Fatima" in the context of values in contemporary society". For example, Sister Emmanuel describes: "With regard to the Marian Apparitions of Medjugorje, Our Lady speaks of the end of the war, namely with Marija Pavlovic, to whom the Virgin introduces herself as "Queen of Peace" and that the war in the Balkans would end soon»", while Sister Bettwy has written that «Patricia Talbot points out to " "a conditional World War III, involving the United States and China, which might lead to a loss of faith by people" $»{ }^{9}$. Furthermore, Patricia Talbot said that the Virgin told her «some Secrets (consisting of three parts), where part of them should be kept secret, and the other part should be revealed to the Pope John Paul II»"${ }^{10}$. Marija Pavlovic has also received nine Secrets by Divine Mother.

Likewise, António Borelli Machado [9] describes some of these same events that occurred in Fatima:«On the sixth apparition, on 13th October 1917, the Virgin said to shepherds: "I would like to ask you to build in this place a chapel in My honor. I am the Lady of the Rosary... The war will soon be over, and the military will return to their homes...". At this moment Lucia exclaimed: "Look at the Sun! .. and at that moment the Sun... began to swirl like a wheel of fire, throwing beams of light... at last, the Sun returned to its place just as it had come down"»" ${ }^{11}$.

Moreover, Sister Lucy said that she has also received some Secrets from the Virgin [10]: «On 13th July 1917, the Secrets were revealed by the Virgin to me, Jacinta and Francisco. They consist of three closely related things.... Then Our Lady said to them: "You have seen Hell, where souls go because of sin .... The war will end (1914-1918), but if mankind do not cease to offend God, another worse war will begin .... To prevent it, I will ask you for the consecration of Russia to my Immaculate Heart and communion on the first Saturdays ... At last, My Immaculate Heart will triumph. The Pope will consecrate Russia to $\mathrm{Me}$, and there will be some time of peace in the world» ${ }^{12}$.

Finally, the phenomenon of "spontaneous healing" that some pilgrims have experienced both in Medjugorje and El Cajas, they have also occurred in Fatima, in the last century, as described by Luciano Cristino [11] : "On 13th June 1917, Lucia asked about the cure of a patient, to which the Virgin of Fatima replied: "If she convertes, then she will be healed during the year" $"{ }^{13}$.

\footnotetext{
7 When the "seers" received their "Divine Messages", they later found that the "Message of Fatima" had very similar contente to what they had received from the Divine Mother, but associated with contemporary society.

${ }^{13}$ Regarding the theme of spontaneous cures, for example, read: Martins, Paulo. A perspective on the "spontaneous" cures associated with the Sacred. International Journal of Humanities, Social Sciences and Education, Vol.7, Issue 5. 2020. (accepted for publication)
} 


\section{CONCLUSION}

The relevance of the "Message of Fatima" for changing values of society over time is unquestionable, and so there have been several studies on this subject [12]. Nevertheless, there is still a great deal of research on the theme of the "Sacred in contemporary society" [13] to be performed by researchers, notably on some phenomena that has occurred both in Medjugorje and El Cajas. These two Marian Apparitions have given a "new look" to the "Message of Fatima", namely the sacred content (timeless) of the Marian Apparitions, [14] since it coincides in many aspects with the content of the "Message of Fatima".

\section{References}

[1] Fazio, Mariano. Fundamentos da Cultura Contemporânea. Editora Moinho Velho.2015.

[2] Connell, Janice. Meetings with Mary:Visions of the Blessed Mother. Penguin Random House. 1996.

[3] Martins, Paulo. O fim do Romantismo Lunar 50 anos depois da chegada do homem à Lua. Religião e Vida: Labirintos da Existência, Em: Brissos-Lino, J. e Pinto, P., Edições Lusófonas. 2020, (accepted for publication).

[4] Cristino, Luciano and Duarte, Marco. Francisco e Jacinta Marto - Candeias que Deus acendeu. Santuário de Fátima. 2012.

[5] Reju, Daniel. Le Troisième secret de Fátima. Éditions du Rocher. 1981.

[6] Franco, José and Reis, Bruno. Fátima: Lugar Sagrado Global. Círculo de Leitores. 2017.

[7] Maillard, Sister Emmanuel. Medjugorje, Trionfe du Coeur. Éditions des Béatitudes. 2009.

[8] Bettwy, Sister Isabel. I am The Guardian of The Faith. Franciscan University Press. 1991.

[9] Machado, António. As Aparições e a Mensagem de Fátima nos manuscritos da Irmã Lúcia. Companhia Editora do Minho. 1998.

[10] de Jesus, Sister Lúcia. Memórias da Irmã Lúcia. A Pastorinha de Fátima. Edições Loyola. 2016.

[11] Cristino, Luciano. As Aparições de Fátima a partir de Documentos. Santuário de Fátima. 2017.

[12] Fernandes, Joaquim and Fernandes, Fernando and Berenguel, Raul et al. Fátima. Mais Além da Fé. Book Cover Editora. 2019.

[13] Martins, Paulo. "A perspective on the" spontaneous "cures associated with the Sacred", in IJHSSE Journal.

[14] Olati, Adilakshmi. The Mother. Mother Meera Foundation. 2008. 